\title{
Multi-Objective Sensitivity Analyses for Power Generation Mix: Malaysia Case Study
}

\author{
Siti Mariam Mohd Shokri", Nofri Yenita Dahlan", Hasmaini Mohamad ${ }^{\#}$ \\ ${ }^{\text {\# }}$ Faculty of Electrical Engineering, Universiti Teknologi MARA (UiTM), Shah Alam, Malaysia \\ E-mail: maryam.mohdshokri@yahoo.com,nofriyenita012@ppinang.uitm.edu.my,hasmaini@salam.uitm.edu.my
}

\begin{abstract}
This paper presents an optimization framework to determine long-term optimal generation mix for Malaysia Power Sector using Dynamic Programming (DP) technique. Several new candidate units with a pre-defined MW capacity were included in the model for generation expansion planning from coal, natural gas, hydro and renewable energy (RE). Four objective cases were considered, 1) economic cost, 2) environmental, 3) reliability and 4) multi-objectives that combining the three cases. Results show that Malaysia optimum generation mix in 2030 for, 1) economic case is $48 \%$ from coal, $41 \%$ from gas, $3 \%$ from hydro and $8 \%$ from RE, 2) environmental case is $19 \%$ from coal, $58 \%$ from gas, $11 \%$ from hydro and $12 \%$ from $\mathrm{RE}, 3$ ) for reliability case is $64 \%$ from coal, $32 \%$ from gas, $3 \%$ from hydro and $1 \%$ from RE and 4 ) multi-objective case is $49 \%$ from coal, $41 \%$ from gas, $7 \%$ from hydro and $3 \%$ from RE. The findings of this paper are the optimum generation mix for Malaysia from 2013 to 2030 which is less expensive, substantially reduce carbon emission and that less risky.
\end{abstract}

Keywords - generation mix; dynamic programming (dp); single objective; multi-objective

\section{INTRODUCTION}

The recent issues of generation mix in Malaysia are: 1) over-dependency on a certain fuel type (oil, natural gas, coal and hydro), which is not viable for a long-term option, 2) lack of availability for a competitive, sustainable and alternative commercial energy sources for the long-term. This becomes big challenges for Malaysia power sector as highlighted in the Energy Service Conference 2016. These have led Malaysia to find other alternative resources to generate electricity. Some possible options are: 1) coal, however, this leads to the dependency on imported coal and will increase gas carbon emission; 2) natural gas, however, its capacity has a contracted gas volume and depletion of gas reserves; 3) hydro, however, there is limited hydro potential in Peninsular since it is complex technology and high investment; and 4) renewable energy (RE), however, the resources are interruptible and expensive. It is critical for Malaysia power system to find an optimum future fuel mix strategy to ensure sustainability of supply. It is important and timely to determine the optimum future generation mix for Malaysia considering various fuels, economic and policy factors in ensuring cost effectiveness, sustainable and secure power generation.

Generation expansion problem can be expressed as a highly constrained, large scale, nonlinear, discrete optimization problem, mix-integer and stochastic optimization problem that typically aims at identifying the selection of the locations and technologies to use [1], [2], [3], [4]. There are numbers of computational optimization techniques that can be used for determining the optimal generation mix. The traditional approaches to solve the generation planning problem are based on mathematical programming methods such as Linear Programming (LP), mixed integer linear programming (MILP) model [3], [4], [5], [6] and Dynamic Programming (DP) [7]. The metaheuristic approach such as Genetic Algorithm (GA) [2][8] that is among popular AI-based techniques for generation mix optimization, Evolutionary Programming (EP) [9], [10], [11], Evolutionary Strategy (ES) [12] and Partial Swarm Optimization (PSO) [13], [14] are applied to solve expansion generation mix problem. A comparative study on the techniques used for generation expansion planning has been performed in [1], [15].

Generation mix problem is to determine what to build (choice of technology), how much to build (capacity of the plant), and when to build (suitable time for expansion). The choice of which technology to be included in the generation mix is essential, yet difficult because each technology has its own advantages and disadvantages [16].

The open literature is limited for studying the generation mix for Malaysia [10] using Evolutionary Programming (EP) 
to determine optimal generation mix planning at the least cost for $4,100 \mathrm{MW}$ additional capacity as announced by Malaysia Energy Commission. The combination of four technology options namely nuclear, coal, natural gas and renewable energy (RE), authors of [11] have extended the study to compare three objectives function that compared in term of economic cost, socio-environmental and power system reliability. However, both studies did not consider a long-term generation mix for Malaysia. On the other hand, [17] presents a long-term generation mix model to minimize the total cost of supplying electricity. After that, [7] proposes DP with efficiency multi-criteria decision technique in modelling multi-objective (i.e. to minimize the cost and to minimize $\mathrm{CO}_{2}$ emission) of the long-term generation mix. They also conducted a sensitivity analysis to evaluate the impact of the inclusion of nuclear in the generation mix, increasing the gas price and the RE target policy. This paper did not consider a power system reliability as the objective function.

Section II presents the mathematical formulation of the DP-generation mix and display the test data. The optimization results and discussion described in section III. Section IV gives the conclusion and finding of the paper.

\section{MATERIAL AND METHOD}

\section{A. DP-based Generation Mix Model}

DP is applied over a time horizon to find a set of optimal decision to minimize the objective function subjected to several constraints. The DP is an approach that transforms a complex problem into a simpler sub-problem. Its main characteristic lies in the way that optimization is solved in multi-stages. In the DP-based generation mix model, a state is defined as the existing units plus the new units. This model selects the generation options each year among the set of generation technologies until it reaches the optimization horizon.

The DP-based generation mix is tested using four cases of optimization objectives; 1) economic objective which is to minimize the total cost of generation expansion, 2) environmental objective which is to minimize the total carbon emission, 3) reliability objective which is to maximize the reliability of system by minimizing the loss of load expectation (LOLE) and 4) multi-objectives which is to minimize the normalized index.

The optimization model's objective function and constraints are presented below.

\section{1) Least Cost Modelling}

The DP-based generation mix is developed to minimize the total cost of generation expansion, including investment and operating costs. Some factors that contribute to the generation cost of the technologies are included in the generation mix model. These include investment cost, construction time, plant lifetime, fixed and variable O\&M costs, fuel cost and fuels escalation rate. The total cost of future generation expansion, considering the generation cost profiles of different technologies, is given by the following equation:
$T C=\min \sum_{t=1}^{T}\left\{P C_{a n}\left(X_{t}\right)_{t}+I C\left(U_{t}\right)_{t}+F O M_{a n}\left(X_{t}\right)_{t}\right.$

where $T C$ is the total cost of generation mix over the simulation horizon, PCall, $t$ is the total production cost of all the generating units in the system at year $t, I C t$ is the total investment cost of the new investments at year $t, X t$ is the cumulative capacity ( $\mathrm{MW}$ ) vector in year $t, U t$ is the capacity addition vector in year $\mathrm{t}$ and $\mathrm{T}$ is the lifetime of the new plant. Multiplying the marginal cost by the energy produced gives the production cost of each unit. The energy produced each year is computed by performing economic dispatch for each segment of the load duration curve (LDC). FOMall, $t$ is the total fixed O\&M cost of all the generating units at year $t$, VOMall, $t$ is the total variable O\&M cost of all the generating units at year $t$ and $C C t$ is the total carbon emission cost of coal and combined cycle technologies at year $t$. Economic dispatch is modeled in the DP-based generation mix to calculate the power dispatch by the generating unit in the system and production cost of each unit [7].

\section{2) Least Carbon Emission Modelling}

The next model is developed to minimize the total carbon emission as an environmental objective function. It can be determined based on the carbon content of the different unit technologies. The total carbon emission for future expansion as the following equation:

$$
\mathrm{TCO}_{2}=\min \sum_{t=1}^{T}\left\{\mathrm{CI}_{t}\right\}
$$

where $C I_{t}$ is the total carbon emission at year $t$.

\section{3) Least Loss of Load Expectation (LOLE) Modelling}

One of the main objective in generation mix optimization is for ensuring the long-term security of Malaysia power supply. In power supply section, generator outage can occur due to planned maintenance or mechanical failure that may leave the system with the insufficient generating capacity to meet load demand. The loss of load probability and loss of load expectation of the system is given by the following equation:

$$
\begin{gathered}
\text { LOLP }=\sum_{s=1}^{s} \sum_{i=1}^{n} P_{i}((\mathrm{Cl}-\mathrm{Ca}(\mathrm{l})) \leqslant \mathrm{Pd}) \\
\text { LOLE }=\sum_{t=1}^{T} d \cdot \operatorname{LOLP}
\end{gathered}
$$

where $C z$ is actual capacity for state $i, C a$ is a capacity outage, $P d$ is load demand and $d$ is duration for each segment in an hour. Equation (3) indicates that loss of load probability (LOLP) is probability loss of load occur when the system load exceeds the generating capacity available for use.

\section{4) Least Normalized Index Modelling}

The multi- objectives is a model combining the three cases of objective functions. Each individual case objective has different units and scales; therefore, the objective is 
formulated as the weighted sum of normalized values of these three cases of objectives. The objective function from are scaled between 0 and 1. For each of the three case objectives, a minimum and maximum value are defined. The normalized index of multi-objectives function is given by the following equation:

$$
\begin{aligned}
& f_{\text {nom }}=\frac{f-f_{\text {min }}}{f_{\max }-f_{\min }} \\
& N_{\mathrm{min}}=w_{1} T C_{\mathrm{mmm}}+w_{2} T C O_{\text {nomm }}+w_{2} \text { LOLE } E_{\mathrm{num}} \\
& w_{1}=w_{2}=w_{2}=1
\end{aligned}
$$

where $f$ is the actual value, $f_{\min }$ and $f_{\max }$ is minimum and maximum value of objective function. Equation (6) indicates that the least normalized index is equal to summation of three normalized objective functions multiplied by weights. The weights of each objective in this study is set similar as shown in equation (7).

\section{5) Constraints Modelling}

- Generation capacity larger than demand capacity plus some reserve margin.

$$
X_{t}=X_{t-1}+U_{t}-K_{t}, \forall t \in T
$$

- Reserve margin lies between the minimum and maximum reserve.

$$
\mathbb{R}^{\min } \leq \mathbb{R}\left(X_{t}\right) \leq \mathbb{R}^{\max }, \forall t \in T
$$

where $K t$ is the capacity retirement, $T$ is the optimization horizon, $R$ is the reserve margin resulting from the generation capacity $X t$, and $\mathrm{R}^{\min }$ and $\mathrm{R}^{\max }$ are the minimum and maximum reserve requirement each year. Equation (8) indicates that the cumulative capacity at year $t$ is equal to the capacity of the previous year, plus the new capacity built at year $t$, minus the capacity retirement happening at year $t$. Equation (9) constraints the installed capacity to be within the minimum and maximum reserve requirements allowed in the system.

\section{B. Test Data}

The proposed model has been implemented in Matlab programming. The analysis has been tested on Malaysia's Power System. The actual data was collected on 2012 from the Energy Commission (EC), Tenaga Nasional Berhad (TNB), U.S. Energy Information Administration (EIA) and International Energy Agency (IEA). The planning horizon consists of a period of seventeen years (2013-2030), and base year of 2012 with install generation capacity of $21,871 \mathrm{MW}$. The system consists of one hundred thirty-two generating units from five different fuel technologies namely coal, gas, hydro, oil and RE as shown in Appendix. Three power plants as highlighted in bold in the Appendix are extending their expiry of the power purchase agreement's (PPA). Two power plants (Segari Energy venture and Genting Sanyen Power) will be granted a 10-year PPA extension and will be retired on 2027 and 2026 respectively. Meanwhile, SJ Sultan Iskandar (combined cycle) plant will extend its services for another 5 years and will be retired on 2022.

Fig. 1 shows a six-segment of discretised load duration curve (LDC) for Malaysia. The hourly load demand data is obtained from EC for the year 2012. Table 1 shows a demand and duration for each segment from LDC.

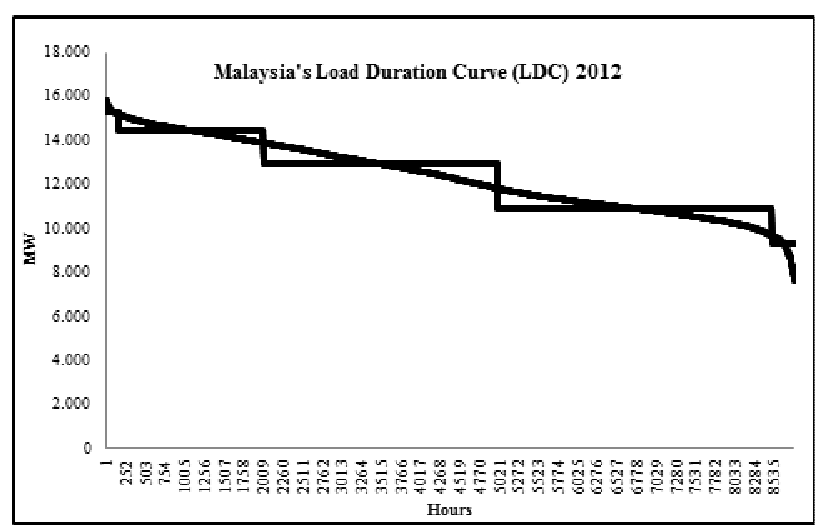

Fig. 1 Six-segment discretised Load Duration Curve (LDC) for Malaysia

Table 2 shows a long-term load growth forecast from the year 2013 to 2030. Average period growth rate forecast for the year 2013 to 2015 is $3.7 \%$, the year 2016 to 2020 is $3.3 \%$ and year 2021 to 2030 is around $1.6 \%$. This load growth is significant to be acquainted with the quality of load demand, reserve margin and total install capacity of the power plant.

TABLE I

DEMAND AND DURATION FOR SIX-SEGMENT

\begin{tabular}{|l|c|c|c|c|c|c|}
\hline Segment & $\mathbf{1}$ & $\mathbf{2}$ & $\mathbf{3}$ & $\mathbf{4}$ & $\mathbf{5}$ & $\mathbf{6}$ \\
\hline $\begin{array}{l}\text { Demand } \\
\text { (MW) }\end{array}$ & 15,644 & 15,287 & 14,440 & 12,913 & 10,896 & 9,309 \\
\hline Duration (h) & 16 & 144 & 1840 & 3000 & 3500 & 284 \\
\hline
\end{tabular}

TABLE II

LOAD GROWTH FORECASTED 2013-2030

\begin{tabular}{|c|c|c|c|c|c|c|c|}
\hline Year & $\mathbf{2 0 1 3}$ & $\mathbf{2 0 1 4}$ & $\mathbf{2 0 1 5}$ & $\mathbf{2 0 1 6}$ & $\mathbf{2 0 1 7}$ & $\mathbf{2 0 1 8}$ & $\mathbf{2 0 1 9}$ \\
\hline Growth (\%) & 4.5 & 3.6 & 3.2 & 3.8 & 3.2 & 3.3 & 3.0 \\
\hline Year & $\mathbf{2 0 2 0}$ & $\mathbf{2 0 2 1}$ & $\mathbf{2 0 2 2}$ & $\mathbf{2 0 2 3}$ & $\mathbf{2 0 2 4}$ & $\mathbf{2 0 2 5}$ & $\mathbf{2 0 2 6}$ \\
\hline Growth (\%) & 3.5 & 2.9 & 2.1 & 0.7 & 1.9 & 1.8 & 1.7 \\
\hline Year & $\mathbf{2 0 2 7}$ & $\mathbf{2 0 2 8}$ & $\mathbf{2 0 2 9}$ & $\mathbf{2 0 3 0}$ & & & \\
\hline Growth (\%) & 1.7 & 1.6 & 1.5 & 1.4 & & \\
\cline { 1 - 4 }
\end{tabular}


TABLE III

TECHNICAL OF MODELLING PARAMETERS

\begin{tabular}{|l|l|c|c|c|c|c|c|}
\hline Parameter & Unit & \multicolumn{2}{|c|}{ Coal } & \multicolumn{2}{|c|}{ Gas } & Hydro & RE \\
\hline Name & unit & $\begin{array}{c}\text { PG } \\
\mathbf{0 1}\end{array}$ & $\begin{array}{c}\text { PG } \\
\mathbf{0 2}\end{array}$ & $\begin{array}{c}\text { PG } \\
\mathbf{0 3}\end{array}$ & $\begin{array}{c}\text { PG } \\
\mathbf{0 4}\end{array}$ & $\begin{array}{c}\text { PG } \\
\mathbf{0 5}\end{array}$ & $\begin{array}{c}\text { PG } \\
\mathbf{0 6}\end{array}$ \\
\hline Net capacity & MW & 700 & 500 & 600 & 400 & 150 & 200 \\
\hline Heat rate & MBTU/MWh & 8.13 & 8.13 & 9.37 & 9.37 & 5.77 & 4.31 \\
\hline $\begin{array}{l}\text { Construction } \\
\text { time }\end{array}$ & Years & 4 & 4 & 5 & 5 & 5 & 2 \\
\hline Plant life time & Years & 40 & 40 & 30 & 30 & 40 & 40 \\
\hline
\end{tabular}

TABLE IV

COST AND FINANCING OF MODELLING PARAMETERS

\begin{tabular}{|l|l|c|c|c|c|c|}
\hline Parameter & Unit & Coal & Gas & Hydro & RE & Oil \\
\hline Carbon intensity & tc/MBTU & 0.0258 & 0.0148 & 0 & 0 & 0 \\
\hline Fixed O\&M & $\mathbf{\$ / k W / y r}$ & 27.53 & 11.70 & 13.63 & 11.68 & 21.50 \\
\hline Variable O\&M & $\mathbf{\$} / \mathbf{M W h}$ & 4.59 & 2 & 2.43 & 0 & 3.17 \\
\hline fuel cost & $\mathbf{\$ M B T U}$ & 2.46 & 4.26 & 1 & 1 & 24.37 \\
\hline Fuel escalation rate & $\mathbf{\%}$ & 0.5 & 1.5 & 0 & 0 & 1.0 \\
\hline Force Outage rate (FOR) & - & 0.06 & 0.04 & 0.05 & 0.08 & 0.10 \\
\hline
\end{tabular}

This study considers four generation technologies i.e. coal, gas, hydro and RE that available to be selected by DP each year for future additional generation expansion. The technical and cost characteristics of the expansion plants are shown in Table 3 and Table 4. Similar costs data have been used for the existing system.

\section{RESULTS AND DICUSSION}

The DP-based generation mix model is analysed for four case studies. A case study has been carried out using the presented model to determine long-term optimum Malaysia generation mix with an 18-year planning period. It will be 64 possible options or also called states comes from 6 candidate units of technology for DP selection.

\section{A. Case 1: Economic Objective}

In this case, the generation mix is to minimize the total cost of power generation. The optimum generation mix for Malaysia at minimum cost objective in the year 2030 is $48 \%$ from coal, $41 \%$ from gas, $3 \%$ from hydro and $8 \%$ from RE with total install capacity is 29,439 MW, as shown in Fig. 2.

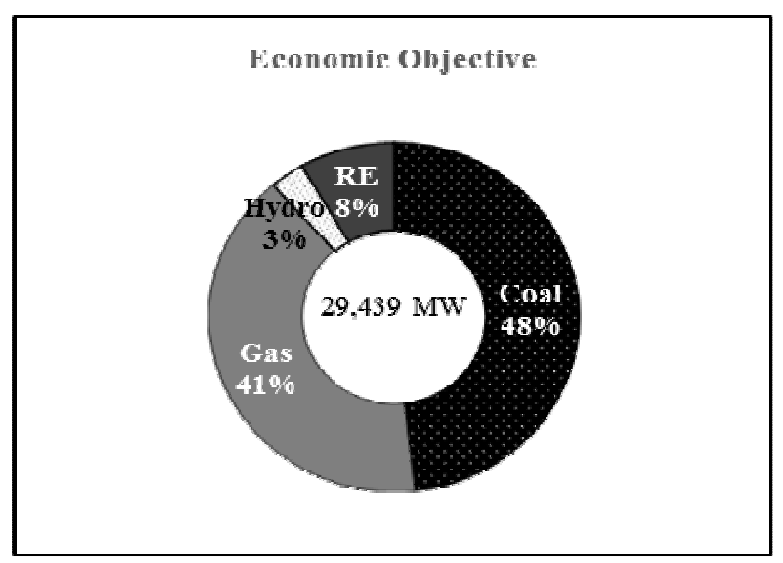

Fig. 2 Malaysia generation mix on 2030 with economic objective
Table 5 shows the result of optimum installed capacity for each type of technologies considering the economic objective. The optimum option is on option 54 from all 64 of possible options. The coal has the highest capacity of 14,201 MW followed by the gas with 11,911 MW the RE with 2,429 MW and hydro with $901 \mathrm{MW}$. The optimum total cost over the 18 years planning period considering economic objective is $\$ 96$ billion. The carbon emission and LOLE for this least cost objective are 449 million $\mathrm{tCO}_{2}$ and 1.71 days per year respectively.

TABLE V

OPTIMUM INSTALLED CAPACITY, TOTAL COST, TOTAL $\mathrm{CO}_{2}$ AND LOLE FOR ECONOMIC OBJECTIVE

\begin{tabular}{|c|c|c|c|c|c|}
\hline Option & \multicolumn{2}{|c|}{ Coal (MW) } & Gas (MW) & $\begin{array}{l}\text { Hydro } \\
\text { (MW) }\end{array}$ & $\begin{array}{c}\mathrm{RE} \\
(\mathrm{MW})\end{array}$ \\
\hline 54 & \multicolumn{2}{|c|}{14,201} & 11,911 & 901 & 2,429 \\
\hline \multicolumn{2}{|c|}{ Total Cost $(\$)$} & \multicolumn{2}{|c|}{ Total $\mathrm{CO}_{2}(\mathrm{tc})$} & \multicolumn{2}{|c|}{ LOLE (days/year) } \\
\hline \multicolumn{2}{|c|}{$96,065,575,890.62$} & \multicolumn{2}{|c|}{$449,433,569.89$} & \multicolumn{2}{|c|}{1.71} \\
\hline
\end{tabular}

Fig. 3 shows the result of the expansion plants that are selected by the DP each year from 2013 until 2030 to meet the demand growth and to replace the retirement units. In the year 2015, there is no expansion of unit as the install capacity has met the demand and reserve requirement in that year. Throughout the years, gas technology has been shown as the favourite technology selected by DP.

\section{B. Case 2: Environmental Objective}

In the case of environmental objective, the optimum generation mix in the year 2030 is $19 \%$ from coal, $58 \%$ from gas, $11 \%$ from hydro and $12 \%$ from RE, with total install capacity is $29,839 \mathrm{MW}$ as shown in Fig. 4. The coal technology in the generation mix reduces from $48 \%$ in the case of the economic objective to $19 \%$ in the case of the environmental objective. This is due to the coal technology that has the highest carbon content compared to the other technologies. 


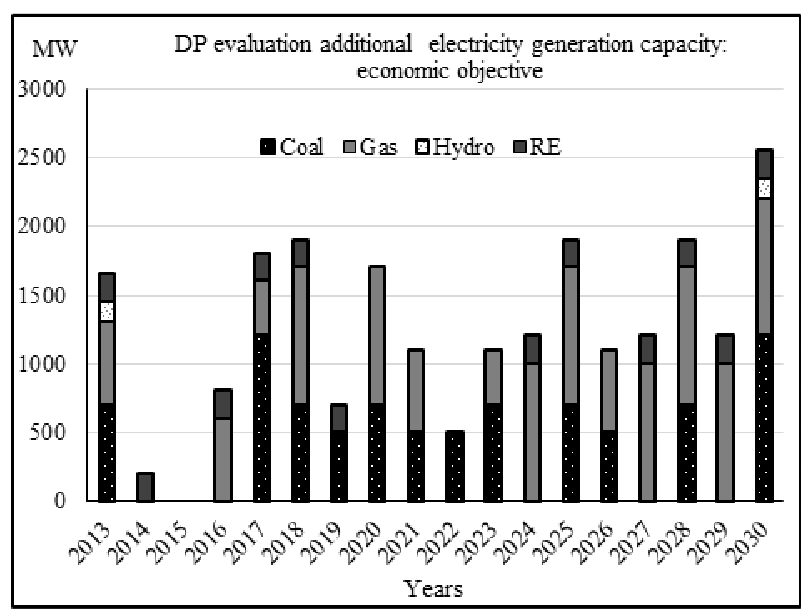

Fig. 3 DP evaluation additional electricity generation capacity for economic objective

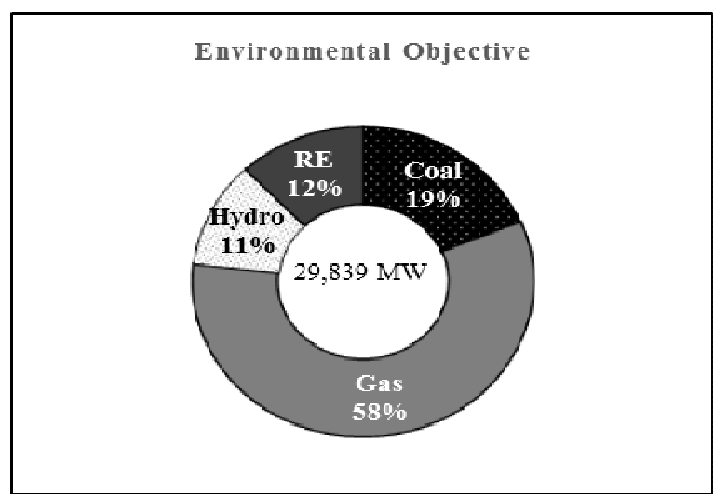

Fig. 4 Malaysia generation mix on 2030 with environmental objective

The optimal solution is option 61 with install capacity of 17,310 MW from the gas, 5,601 MW from the coal, 3,628 MW and 3,300 MW from the RE and hydro respectively. Table 6 shows that the total carbon emission considering environmental objective reduced by $18.72 \%$ as compared to total carbon emission in the case of the economic objective.

Fig. 5 shows that coal technology was not selected by DP due to higher carbon emission. In the year 2024 and 2026, technology selection was reduced since the installed capacity has met the demand and reserve requirement in that year.

\section{Case 3: Reliability Objective}

In the case of reliability objective, the optimum generation mix in the year 2030 is $64 \%$ from coal, $32 \%$ from gas, $3 \%$ from hydro and $1 \%$ from RE as shown in Fig. 6.

TABLE VI

OPTIMUM INSTALLED CAPACITY, TOTAL COST, TOTAL $\mathrm{CO}_{2}$ AND LOLE FOR ENVIRONMENTAL OBJECTIVE

\begin{tabular}{|c|c|c|c|c|}
\hline Option & Coal (MW) & Gas (MW) & $\begin{array}{c}\text { Hydro } \\
(\mathrm{MW})\end{array}$ & $\begin{array}{c}\text { RE } \\
(\mathrm{MW})\end{array}$ \\
\hline 61 & 5,601 & 17,310 & 3,300 & 3,628 \\
\hline \multicolumn{2}{|c|}{ Total Cost $(\$)$} & \multicolumn{2}{|c|}{ Total $\mathrm{CO}_{2}$ (tc) } & LOLE (days/year) \\
\hline $110,250,420,884.15$ & $365,297,466.89$ & \multicolumn{2}{c|}{0.57} \\
\hline
\end{tabular}

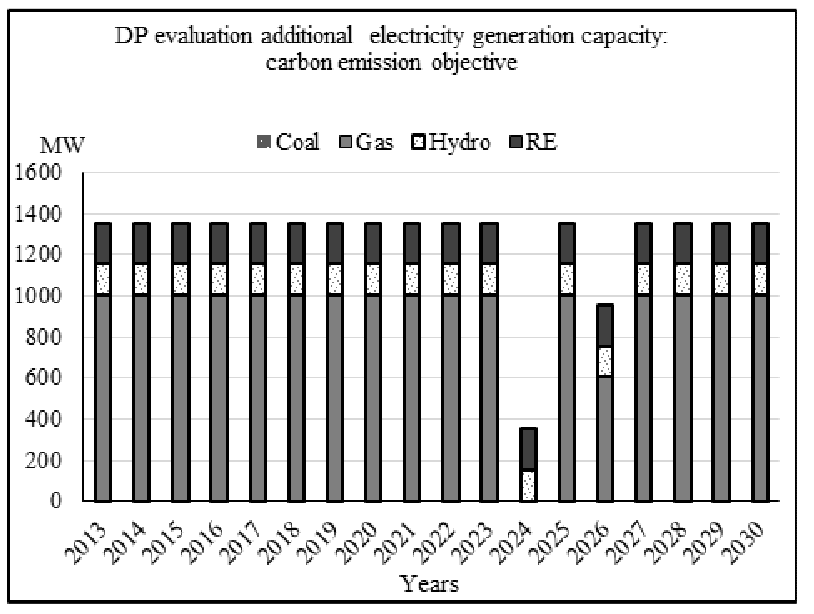

Fig. 5 DP evaluation additional electricity generation capacity for environmental objective

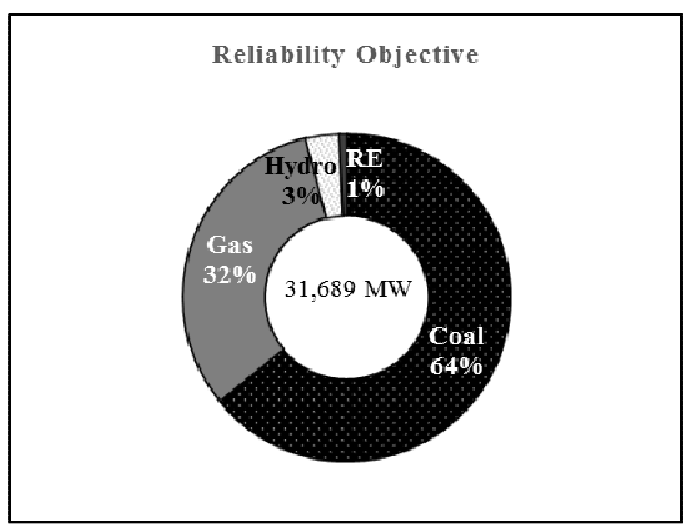

Fig. 6 Malaysia generation mix on 2030 with reliability objective

Table 7 shows that the optimum option is on option 30 . The highest installed capacity in the generation mix is contributed by the coal with 20,300 MW. This is followed by gas with 10,109 MW, the hydro with 1,049 MW and the RE technology with $229 \mathrm{MW}$. The installed capacity of the coal and hydro technologies have significantly increased from the case of the economic objective. It is found that the LOLE considering reliability objective is more than $100 \%$ lower than the LOLE with the case of economic and environmental objectives. This indicates that by minimizing LOLE in power generation mix planning could maximize the power system reliability.

TABLE VII

OPTION, TOTAL COST, TOTAL CARBON EMISSION AND LOLE FOR RELIABILITY OBJECTIVE

\begin{tabular}{|c|c|c|c|c|}
\hline Option & $\begin{array}{c}\text { Coal } \\
(\mathrm{MW})\end{array}$ & $\begin{array}{c}\text { Gas } \\
(\mathrm{MW})\end{array}$ & $\begin{array}{c}\text { Hydro } \\
(\mathrm{MW})\end{array}$ & $\begin{array}{c}\text { RE } \\
(\mathrm{MW})\end{array}$ \\
\hline 30 & 20,300 & 10,109 & 1,049 & 229 \\
\hline \multicolumn{2}{|c|}{ Total Cost (\$) } & \multicolumn{2}{|c|}{ Total $\mathrm{CO}_{2}(\mathrm{tc})$} & \multicolumn{2}{|c|}{ LOLE (days/year) } \\
\hline $101,997,663,107.35$ & $480,950,452.39$ & \multicolumn{2}{|c|}{$4.33 \mathrm{E}-6$} \\
\hline
\end{tabular}

There are no technologies expansion in the year 2014 and 2015 as shown in result DP additional expansion at Fig. 7. Coal has been the most selected technology throughout the year because it is the most contributing technology in maximizing reliability. Less capacity of RE has been 
selected in this case as RE has a lower capacity factor hence availability in the system.

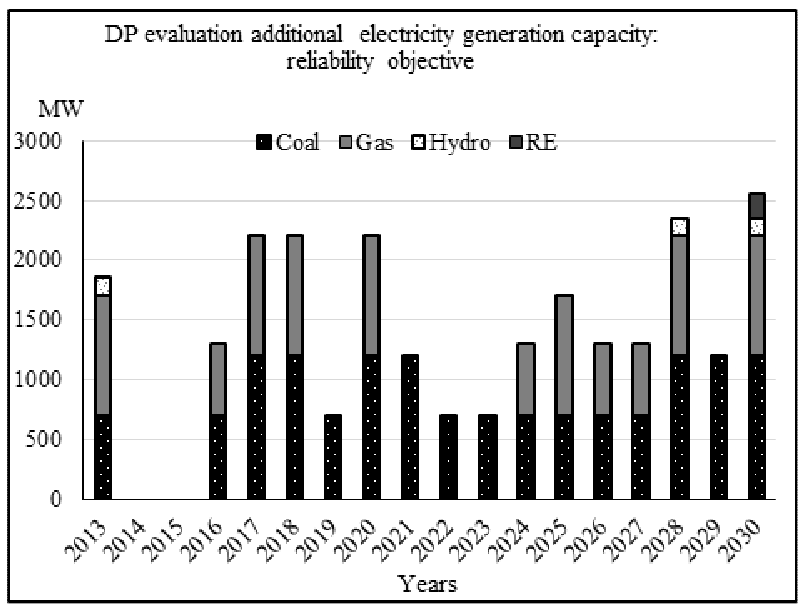

Fig. 7 DP evaluation additional electricity generation capacity for reliability objective

\section{Case 4: Multi-Objectives}

Case four presents generation mix considering simultaneous multi-objectives i.e. economic cost, environmental impact, and system reliability. The objective value for the three single objectives was normalized and the optimum generation mix depends on the minimum value of the normalized index. A weighted sum technique [3] was used in this case. The weighted value for each objective function is the same, where the total weight is equal to one. Fig. 8 shows the result of optimum generation mix for the multi-objectives case with $49 \%$ from coal, $41 \%$ from gas, $7 \%$ from hydro and $3 \%$ from RE technology.

Table 8 shows that coal has the highest installed capacity of $15,200 \mathrm{MW}$. This is followed by gas with $12,710 \mathrm{MW}$, hydro with 2,101 MW and RE with 1,030 MW. The total cost for this generation mix is $\$ 104$ billion, total carbon emission is 447 million $\mathrm{tCO}_{2}$ and LOLE is $2.24 \mathrm{E}-3$ days per year. The result of LOLE achieved the reliability policy target that is less than 1day LOLE per year. The weighted sum approach gives the minimum multi-objectives index of 0.4171 with option 42 .

TABLE VIII

OptION, TOTAL COST, TOTAL CARBON EMISSION AND LOLE FOR MULTIOBJECTIVES

\begin{tabular}{|c|c|c|c|c|}
\hline Option & Coal (MW) & $\begin{array}{c}\text { Gas } \\
(\mathrm{MW})\end{array}$ & $\begin{array}{c}\text { Hydro } \\
(\mathrm{MW})\end{array}$ & $\begin{array}{c}\text { RE } \\
(\mathrm{MW})\end{array}$ \\
\hline 42 & 15,200 & 12,710 & 2,101 & 1,030 \\
\hline \multicolumn{3}{|c|}{ Total Cost (\$) } & \multicolumn{3}{|c|}{ Total $\mathrm{CO}_{2}$ (tc) } & \multicolumn{2}{c|}{$\begin{array}{c}\text { LOLE } \\
\text { (days/year) }\end{array}$} \\
\hline \multicolumn{2}{|c|}{$104,032,930,775.29$} & $447,424,628.73$ & $2.24 \mathrm{E}-3$ \\
\hline $\begin{array}{c}\text { Normalize } \\
\text { total cost }\end{array}$ & $\begin{array}{c}\text { Normalize } \\
\text { total } \mathrm{CO}_{2}\end{array}$ & $\begin{array}{c}\text { Normalize } \\
\text { LOLE }\end{array}$ & Normalize Index \\
\hline 0.2639 & 1 & 0 & 0.4171 \\
\hline
\end{tabular}

Fig. 9 shows that no expansion of power plant in the year 2014 and 2015 since the installed capacity has met the demand and reserve in that year.

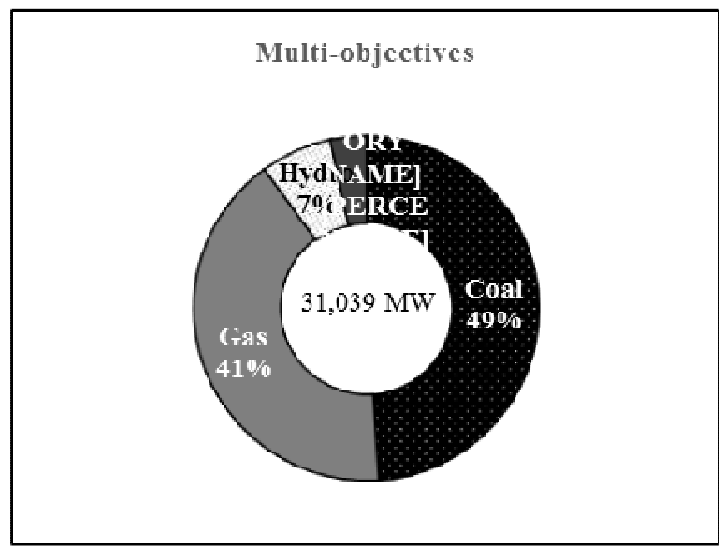

Fig. 8 Malaysia generation mix on 2030 with multi-objectives

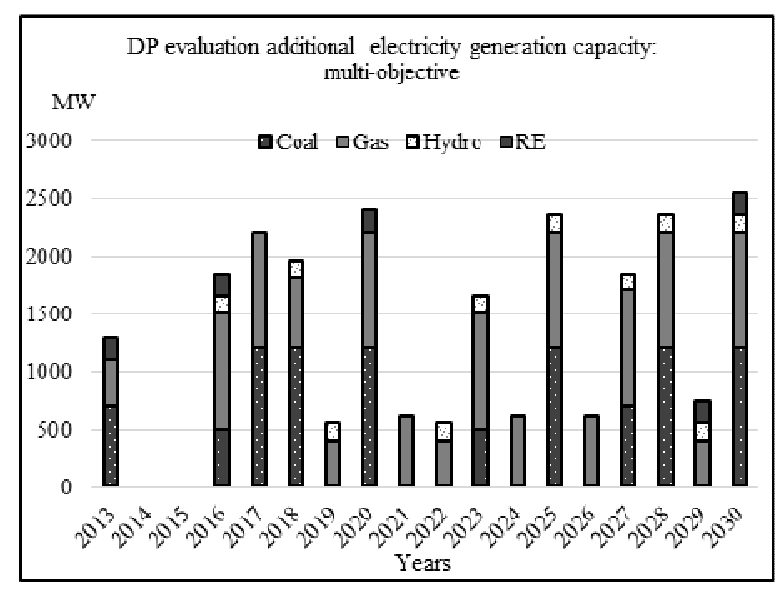

Fig. 9 DP evaluation additional electricity generation capacity for multiobjectives

Table 9 shows load capacity forecasted during the year 2013 until 2030 for six-segment. While Table 10 shows the install capacity of planning time horizon for four case studies.

TABLE IX

LOAD FORECASTED (MW) DURING 2013-2030

\begin{tabular}{|l|c|c|c|c|c|c|}
\hline \multirow{2}{*}{ Year } & \multicolumn{7}{|c|}{ Segment } \\
\cline { 2 - 7 } & 1 & 2 & 3 & 4 & 5 & 6 \\
\hline $\mathbf{2 0 1 3}$ & 16,348 & 15,975 & 15,090 & 13,494 & 11,386 & 9,728 \\
\hline $\mathbf{2 0 1 4}$ & 16,937 & 16,550 & 15,633 & 13,980 & 11,796 & 10,078 \\
\hline $\mathbf{2 0 1 5}$ & 17,478 & 17,080 & 16,133 & 14,427 & 12,174 & 10,401 \\
\hline $\mathbf{2 0 1 6}$ & 18,143 & 17,729 & 16,746 & 14,975 & 12,636 & 10,796 \\
\hline $\mathbf{2 0 1 7}$ & 18,723 & 18,296 & 17,282 & 15,455 & 13,041 & 11,141 \\
\hline $\mathbf{2 0 1 8}$ & 19,341 & 18,900 & 17,853 & 15,965 & 13,471 & 11,509 \\
\hline $\mathbf{2 0 1 9}$ & 19,921 & 19,467 & 18,388 & 16,444 & 13,875 & 11,854 \\
\hline $\mathbf{2 0 2 0}$ & 20,619 & 20,148 & 19,032 & 17,019 & 14,361 & 12,269 \\
\hline $\mathbf{2 0 2 1}$ & 21,217 & 20,732 & 19,584 & 17,513 & 14,777 & 12,625 \\
\hline $\mathbf{2 0 2 2}$ & 21,662 & 21,168 & 19,995 & 17,880 & 15,088 & 12,890 \\
\hline $\mathbf{2 0 2 3}$ & 21,814 & 21,316 & 20,135 & 18,006 & 15,193 & 12,980 \\
\hline $\mathbf{2 0 2 4}$ & 22,228 & 21,721 & 20,517 & 18,348 & 15,482 & 13,227 \\
\hline $\mathbf{2 0 2 5}$ & 22,628 & 22,112 & 20,887 & 18,678 & 15,761 & 13,465 \\
\hline $\mathbf{2 0 2 6}$ & 23,013 & 22,488 & 21,242 & 18,996 & 16,028 & 13,694 \\
\hline $\mathbf{2 0 2 7}$ & 23,404 & 22,870 & 21,603 & 19,318 & 16,301 & 13,927 \\
\hline $\mathbf{2 0 2 8}$ & 23,779 & 23,236 & 21,949 & 19,628 & 16,562 & 14,150 \\
\hline $\mathbf{2 0 2 9}$ & 24,135 & 23,585 & 22,278 & 19,922 & 16,810 & 14,362 \\
\hline $\mathbf{2 0 3 0}$ & 24,473 & 23,915 & 22,590 & 20,201 & 17,046 & 14,563 \\
\hline
\end{tabular}


TABLE X

InSTALl CAPACITy OF PLANNING TIME HORIZON FOR EACH CASE STUdY

\begin{tabular}{|c|c|c|c|c|}
\hline Case Study & $\begin{array}{c}\text { Case 1 } \\
\text { Year }\end{array}$ & $\begin{array}{c}\text { Case 2 } \\
(\mathbf{M W})\end{array}$ & $\begin{array}{c}\text { Case 3 } \\
(\mathbf{M W})\end{array}$ & $\begin{array}{c}\text { Case 4 } \\
\text { MW })\end{array}$ \\
\hline 2013 & $23,280.5$ & $22,980.5$ & $23,480.5$ & $22,930.5$ \\
\hline 2014 & $23,480.5$ & $24,330.5$ & $23,480.5$ & $22,930.5$ \\
\hline 2015 & $22,643.5$ & $24,843.5$ & $22,643.5$ & $22,093.5$ \\
\hline 2016 & $21,868.5$ & $24,618.5$ & $22,368.5$ & $22,368.5$ \\
\hline 2017 & $22,481.5$ & $24,781.5$ & $23,381.5$ & $23,381.5$ \\
\hline 2018 & $23,242.5$ & $24,992.5$ & $24,442.5$ & $24,192.5$ \\
\hline 2019 & $23,942.5$ & $26,342.5$ & $25,142.5$ & $24,742.5$ \\
\hline 2020 & $24,761.5$ & $26,811.5$ & $26,461.5$ & $26,261.5$ \\
\hline 2021 & $25,531.5$ & $27,831.5$ & $27,331.5$ & $26,531.5$ \\
\hline 2022 & $26,031.5$ & $29,181.5$ & $28,031.5$ & $27,081.5$ \\
\hline 2023 & $26,222.5$ & $29,622.5$ & $27,822.5$ & $27,822.5$ \\
\hline 2024 & $26,702.5$ & $29,252.5$ & $28,402.5$ & $27,702.5$ \\
\hline 2025 & $27,272.5$ & $29,272.5$ & $28,772.5$ & $28,722.5$ \\
\hline 2026 & $27,752.5$ & $29,602.5$ & $29,452.5$ & $28,702.5$ \\
\hline 2027 & $28,277.5$ & $30,277.5$ & $30,077.5$ & $29,877.5$ \\
\hline 2028 & 28,619 & 30,069 & 30,869 & 30,669 \\
\hline 2029 & 29,089 & 30,689 & 31,339 & 30,689 \\
\hline 2030 & 29,439 & 29,839 & 31,689 & 31,039 \\
\hline
\end{tabular}

\section{IV.CONCLUSIONS}

In this paper, a DP-based model for four case studies has been developed to find the optimum generation mixes for Malaysia power sector. The model considers characteristics associated with different technologies, such as the investment cost, the O\&M cost, the lifetime, the construction period, the fuel cost and the carbon intensity. The model has been tested on a generation portfolio based on Malaysia power system. The result shows that optimal Malaysia generation mix in 2030 for the economic objective is: $48 \%$ from coal, $41 \%$ from gas, $3 \%$ from hydro and $8 \%$ from RE. The optimum environmental objective is $19 \%$ from coal, $58 \%$ from gas, $11 \%$ from hydro and $12 \%$ from RE. Other than that, the optimum reliability objective is $64 \%$ from coal, $32 \%$ from gas, $3 \%$ from hydro and $1 \%$ from RE. While, the optimum multi-objectives are $49 \%$ from coal, $41 \%$ from gas, $7 \%$ from hydro and $3 \%$ from RE

Economic objective prefers coal technologies to minimize the total cost. On the other hand, environmental objective reduces coal technology in the generation mix, while the coal and hydro technologies are the most contributing technologies to the reliability objective. For multi-objective generation mix, the selection of all the four technologies is seen balance. The research will continue with optimizing under multi-objective decision technique.

\section{ACKNOWLEDGMENT}

We would like to thank Malaysia Ministry of Education and Universiti Teknologi MARA(UiTM) who have sponsored this paper under Research Acculturation Grant Scheme (RAGS), 600- RMI/RAGS 5/3 (194/2014).

\section{REFERENCES}

[1] S. Kannan, S. M. R. Slochanal, and N. P. Padhy, "Application and Comparison of Metaheuristic Techniques to Generation Expansion Planning Problem," vol. 20, no. 1, pp. 466-475, 2005.

[2] A. J. C. Pereira and J. T. Saraiva, "Generation expansion planning (GEP) - A long-term approach using system dynamics and genetic algorithms (GAs)," Energy, vol. 36, no. 8, pp. 5180-5199, Aug. 2011.

[3] H. Tekiner, D. W. Coit, and F. a. Felder, "Multi-period multiobjective electricity generation expansion planning problem with Monte-Carlo simulation," Electr. Power Syst. Res., vol. 80, no. 12, pp. 1394-1405, Dec. 2010.

[4] K. Promjiraprawat and B. Limmeechokchai, "Multi-objective and multi-criteria optimization for power generation expansion planning with CO 2 mitigation in Thailand," vol. 35, no. 3, pp. 349-359, 2013.

[5] Z. A. Muis, H. Hashim, Z. A. Manan, and F. M. Taha, "Optimal Electricity Generation Mix with Carbon Dioxide Constraint," 2004.

[6] P. J. Ramírez, D. Papadaskalopoulos, G. Strbac, and T. T, "CoOptimization of Generation Expansion Planning and Electric Vehicles Flexibility," vol. 7, no. 3, pp. 1609-1619, 2016.

[7] S. M. Mohd Shokri and N. Y. Dahlan, "An Application of the MultiObjective Approach for the Evaluation of Long-Term Electrical Generation Optimum Mix: a Case Study," Int. Rev. Electr. Eng., vol. 9, no. 5, p. 991, 2014.

[8] A. J. C. Pereira and J. T. Saraiva, "A long term generation expansion planning model using system dynamics - Case study using data from the Portuguese/Spanish generation system," Electr. Power Syst. Res., vol. 97, pp. 41-50, Apr. 2013.

[9] S. Kannan, S. M. R. Slochanal, S. Baskar, and P. Murugan, "Application and comparison of metaheuristic techniques to generation expansion planning in the partially deregulated environment," 2007.

[10] N. A. H. A. Mutalib, N. Y. Dahlan, S. A. Abon, M. F. Rajemi, N. M.N.M, and F. Baharum, "Optimum generation mix for Malaysia's additional capacity using evolutionary programming," in 2014 IEEE International Conference on Power and Energy (PECon), 2014, pp. 65-70.

[11] S. A. Abon, N. Y. Dahlan, and Z. M. Yassin, "Evolutionary programming based generation mix model for Malaysia considering cost, environmental and reliability factors," J. Electr. Syst., vol. 2015, no. Specialissue3, pp. 26-34, 2015.

[12] E. Alishahi, M. P. Moghaddam, and M. K. Sheikh-el-eslami, "An investigation on the impacts of regulatory interventions on wind power expansion in generation planning," Energy Policy, vol. 39, no. 8, pp. 4614-4623, 2011.

[13] S. Kannan, S. M. R. Slochanal, P. Subbaraj, and N. P. Padhy, "Application of particle swarm optimization technique and its variants to generation expansion planning problem," Electr. Power Syst. Res., vol. 70, no. 3, pp. 203-210, Aug. 2004.

[14] R. Hemmati, R. Hooshmand, and A. Khodabakhshian, "Reliability constrained generation expansion planning with consideration of wind farms uncertainties in deregulated electricity market," Energy Convers. Manag., vol. 76, pp. 517-526, 2013.

[15] H. Sadeghi, M. Rashidinejad, and A. Abdollahi, "A comprehensive sequential review study through the generation expansion planning," Renew. Sustain. Energy Rev., vol. 67, no. May 2016, pp. 1369-1394, 2017.

[16] A. M. Isa, H. Magori, T. Niimura, and R. Yokoyama, "Multi-Criteria Generation Optimal Mix Planning for Malaysia "s Additional Capacity," vol. 4, no. 4, pp. 221-228, 2010.

[17] S. Mariam, M. Shokri, and N. Y. Dahlan, "Optimum Generation Mix Possibilities for Malaysia Power Sector in 2030," vol. 785, pp. 521525, 2013. 


\section{APPENDIX}

\begin{tabular}{|c|c|c|c|c|}
\hline Power Plant & $\begin{array}{c}\text { Unit } \\
\text { Name }\end{array}$ & $\begin{array}{l}\text { Size } \\
(\mathbf{M W})\end{array}$ & $\begin{array}{l}\text { Unit } \\
\text { Type }\end{array}$ & $\begin{array}{c}\text { PPA } \\
\text { Expiry }\end{array}$ \\
\hline YTL Power Generation & $\begin{array}{c}001- \\
009\end{array}$ & $9 \times 130$ & gas & 2015 \\
\hline Segari Energy Ventures Sdn. Bhd. & $\begin{array}{c}010- \\
011 \\
\end{array}$ & $2 \times 651.5$ & gas & $\begin{array}{r}2017 \\
\mathbf{2 0 2 7} \\
\end{array}$ \\
\hline Power Tek Sdn. Bhd. & $\begin{array}{c}012- \\
015\end{array}$ & $4 \times 110$ & gas & 2015 \\
\hline Por t Dickson Sdn. Bhd. & $\begin{array}{c}016- \\
019\end{array}$ & $4 \times 110$ & gas & 2015 \\
\hline Pahlawan Power Sdn. Bhd. & $\begin{array}{c}020- \\
022\end{array}$ & $3 \times 110$ & gas & 2020 \\
\hline Genting Sanyen Power Sdn. Bhd. & 23 & $1 \times 87$ & gas & 2015 \\
\hline $\begin{array}{l}\text { Genting Sanyen Power Sdn. Bhd. } \\
\text { (GSP Extension) }\end{array}$ & $\begin{array}{c}024- \\
026\end{array}$ & $3 \times 225$ & gas & $\begin{array}{ll}2016 \\
\mathbf{2 0 2 6}\end{array}$ \\
\hline $\begin{array}{l}\text { Teknologi Tenaga Perlis } \\
\text { Consortium Sdn. Bhd. }\end{array}$ & $\begin{array}{c}027- \\
030\end{array}$ & $\begin{array}{c}3 \times 145 \\
1 \times 215\end{array}$ & gas & 2023 \\
\hline Panglima Power Sdn. Bhd. & $\begin{array}{c}031- \\
033\end{array}$ & $\begin{array}{c}2 \times 230 \\
1 \times 260\end{array}$ & gas & 2022 \\
\hline GB3 Sdn. Bhd. & $\begin{array}{c}034- \\
037\end{array}$ & $\begin{array}{l}1 \times 205 \\
3 \times 145\end{array}$ & gas & 2022 \\
\hline Prai Power Sdn. Bhd. & $\begin{array}{c}038- \\
039\end{array}$ & $\begin{array}{l}1 \times 225 \\
1 \times 125\end{array}$ & gas & 2024 \\
\hline $\begin{array}{l}\text { KaparEnergy Ventures Sdn. Bhd. } \\
\text { (KEV) }\end{array}$ & $\begin{array}{c}040- \\
041\end{array}$ & $2 \times 110$ & gas & 2019 \\
\hline $\begin{array}{l}\text { KaparEnergy Ventures Sdn. Bhd. } \\
\text { (KEV) }\end{array}$ & $\begin{array}{c}042- \\
047\end{array}$ & $\begin{array}{l}4 \times 300 \\
2 \times 500\end{array}$ & coal & 2029 \\
\hline TNB JanamanjungSdn. Bhd. & $\begin{array}{c}048- \\
050\end{array}$ & $3 \times 700$ & coal & 2031 \\
\hline Tanjung Bin Power Sdn. Bhd. & $\begin{array}{c}051- \\
053\end{array}$ & $3 \times 700$ & coal & 2031 \\
\hline Jimah Energy Ventures Sdn. Bhd. & $\begin{array}{c}054- \\
055\end{array}$ & $2 \times 700$ & coal & 2033 \\
\hline S.J. Sultan Ismail, Paka & $\begin{array}{c}056- \\
067\end{array}$ & $\begin{array}{c}3 \times 100 \\
7 \times 95 \\
2 \times 87\end{array}$ & gas & 2017 \\
\hline S.J. Jambatan Connaught (CBPS) & $\begin{array}{c}068- \\
074\end{array}$ & $\begin{array}{l}4 \times 130 \\
2 \times 106 \\
1 \times 105\end{array}$ & gas & 2014 \\
\hline S.J. Serdang (GT1 , GT2 \& GT3) & $\begin{array}{c}075- \\
077\end{array}$ & $3 \times 135$ & gas & 2015 \\
\hline
\end{tabular}

\begin{tabular}{|l|c|c|c|c|}
\hline S.J. Serdang (GT4 \& 5) & $\begin{array}{c}078- \\
079\end{array}$ & $2 \times 110$ & gas & 2025 \\
\hline $\begin{array}{l}\text { S.J. Sultan Iskandar, PasirGudang } \\
\text { (PGPS) (Thermal) }\end{array}$ & $\begin{array}{c}080- \\
081\end{array}$ & $2 \times 120$ & gas & 2017 \\
\hline $\begin{array}{l}\text { S.J. Sultan Iskandar, PasirGudang } \\
\text { (PGPS) (Combined Cycle) }\end{array}$ & $\begin{array}{c}082- \\
084\end{array}$ & $\begin{array}{c}2 \times 87 ; \\
1 \times 95\end{array}$ & gas & 2017 \\
\hline $\begin{array}{l}\text { S.J. Sultan Iskandar, PasirGudang } \\
\text { (PGPS) (Open Cycle) }\end{array}$ & $\begin{array}{c}085- \\
086\end{array}$ & $2 \times 110$ & gas & 2016 \\
\hline $\begin{array}{l}\text { S.J. TuankuJaafar, Por t Dickson } \\
\text { (PD1) }\end{array}$ & $\begin{array}{c}087- \\
089\end{array}$ & $\begin{array}{c}2 \times 236 ; \\
1 \times 258\end{array}$ & gas & 2028 \\
\hline $\begin{array}{l}\text { S.J. TuankuJaafar, Por t Dickson } \\
\text { (PD2) }\end{array}$ & $\begin{array}{c}090- \\
092\end{array}$ & $\begin{array}{c}2 \times 230 ; \\
1 \times 250\end{array}$ & gas & 2030 \\
\hline S.J. Kenyir & $\begin{array}{c}093- \\
096\end{array}$ & $4 \times 100$ & hydro & 2025 \\
\hline S.J. Pergau & $\begin{array}{c}097- \\
100\end{array}$ & $4 \times 150$ & hydro & 2037 \\
\hline S.J. Temenggor & $\begin{array}{c}101- \\
104\end{array}$ & $4 \times 87$ & hydro & 2022 \\
\hline S.J. Chenderoh & $\begin{array}{c}105- \\
108\end{array}$ & $\begin{array}{c}3 \times 10.7 ; \\
1 \times 8.4\end{array}$ & hydro & 2022 \\
\hline S.J Bersia & $\begin{array}{c}109- \\
111\end{array}$ & $3 \times 24$ & hydro & 2022 \\
\hline S.J. Kenering & $\begin{array}{c}112- \\
114\end{array}$ & $3 \times 40$ & hydro & 2022 \\
\hline S.J. Woh Sultan Idris II & $\begin{array}{c}115- \\
117\end{array}$ & $3 \times 50$ & hydro & 2022 \\
\hline S.J. Cameron Highland & $\begin{array}{c}118- \\
123\end{array}$ & $\begin{array}{c}4 \times 25 ; \\
2 \times 2.75\end{array}$ & hydro & 2027 \\
\hline Sungai Piah Upper Power Station & 124 & $1 \times 14.6$ & hydro & 2027 \\
\hline Sungai Piah Lower Power Station & 125 & $1 \times 54$ & hydro & 2027 \\
\hline Odak Power Station & 126 & $1 \times 4.2$ & hydro & 2027 \\
\hline Habu Power Station & 127 & $1 \times 5.5$ & hydro & 2027 \\
\hline Kampong Raja Power Station & 128 & $1 \times 0.8$ & hydro & 2027 \\
\hline Kampong Terla Power Station & 129 & $1 \times 0.5$ & hydro & 2027 \\
\hline Robinson Falls Power Station & 130 & $1 \times 0.9$ & hydro & 2027 \\
\hline S.J. Gelugor & 131 & $1 \times 330$ & oil & 2024 \\
\hline $\begin{array}{l}\text { BumibiopowerSdnBhd, Jana } \\
\text { SdnBhd \& Recycle Energy }\end{array}$ & $\begin{array}{l}132 \\
\text { SdnBhd }\end{array}$ & $1 \times 29$ & RE & 2040 \\
\hline
\end{tabular}

